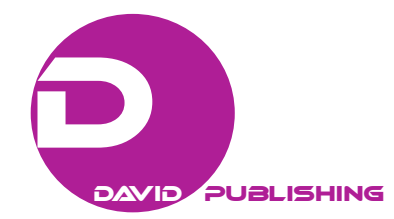

\title{
The Role of Congress in Illegal Immigrations Policy as an Example of the IRCA
}

\author{
Huiyun TANG \\ Shanghai Academy of Social Sciences, Shanghai, China
}

\begin{abstract}
Since 1970s, illegal immigrants have become a hot topic in the US with the increase of number of illegal immigrants, Congress passed Immigration Reform and Control Act of 1986 (IRCA). IRCA is the first legislation towards illegal immigration, which is very important in immigration history. Does this legislation work? What's the role of Congress in controlling illegal immigration and what's the lesson from IRCA? In a short term, IRCA worked. It deterred illegal immigrants and the number of illegal immigrants was on the decline, but in the long run, it failed. From the perspective of decision-making, the role of Congress was not powerful because of the influence of interest groups. Therefore, Congress should be more powerful in the future.
\end{abstract}

Keywords: congress, Immigration Reform and Control Act of 1986, interest groups

\section{Introduction}

At present, comprehensive immigration reform in Congress is into dilemma. Actually, it is not easy to enact immigration reform. Generally speaking, immigration legislation often experiences a long time in Congress, because of the influence of partisanship and interest groups. Immigration Reform and Control Act of 1986 (IRCA) demonstrates it.

IRCA establishes the framework for the following immigration legislation. Is it useful to reduce illegal immigration? What's the role of Congress in illegal immigrations policy and what's lesson should current comprehensive immigration learn from IRCA? This paper will answer these questions based on explanation of the background and legislative process of IRCA.

This paper is divided into seven parts. The first section discusses why Congress enacts IRCA. The second section explains the characteristic of IRCA according to it's content. The core of the paper includes the parts from third section to the sixth section.

The third section and the fourth section analyze employer sanction policy and amnesty policy conflict during the decision-making. The fifth section describes finally conflict about Simpson-Mode Li Motion Bill. The sixth section evaluates the IRCA. The concluding section summarizes the role of Congress during the legislative process of IRCA and lessons of IRCA.

\section{Social Context of Immigration Reform and Control Act of 1986}

Since 1947, the US enforced the Bracero Program, which recruited seasonal workers to the US. This project, which lasted 14 years, not only brought many agriculture workers, but also brought illegal immigrants.

Huiyun TANG, Ph.D., Assistant Researcher, Institute of International Relations, Shanghai Academy of Social Sciences. 
Until the 1970s, with more and more illegal immigrants lived in America, illegal immigration became a hot topic. Under this context, Congress enacted the IRCA. In details, several reasons can account for it. Firstly, more and more illegal immigrants are the main reason.

From Figure 1, we can see that since 1965, the number of illegal immigrants was on the increase. Although there was a decrease of illegal immigrants, on the whole trend, it increased until 1985. Actually, it reached the peak, nearly about 1,800,000. From 1965-1975, illegal immigrants, who were deported increased by $453 \%$. Compared with 1961, it increased by $762 \%$ (Vialet, 1977, p. 2).

Most of the illegal immigrants came from Central America and Mexico and Mexican dominated (see Table 1).

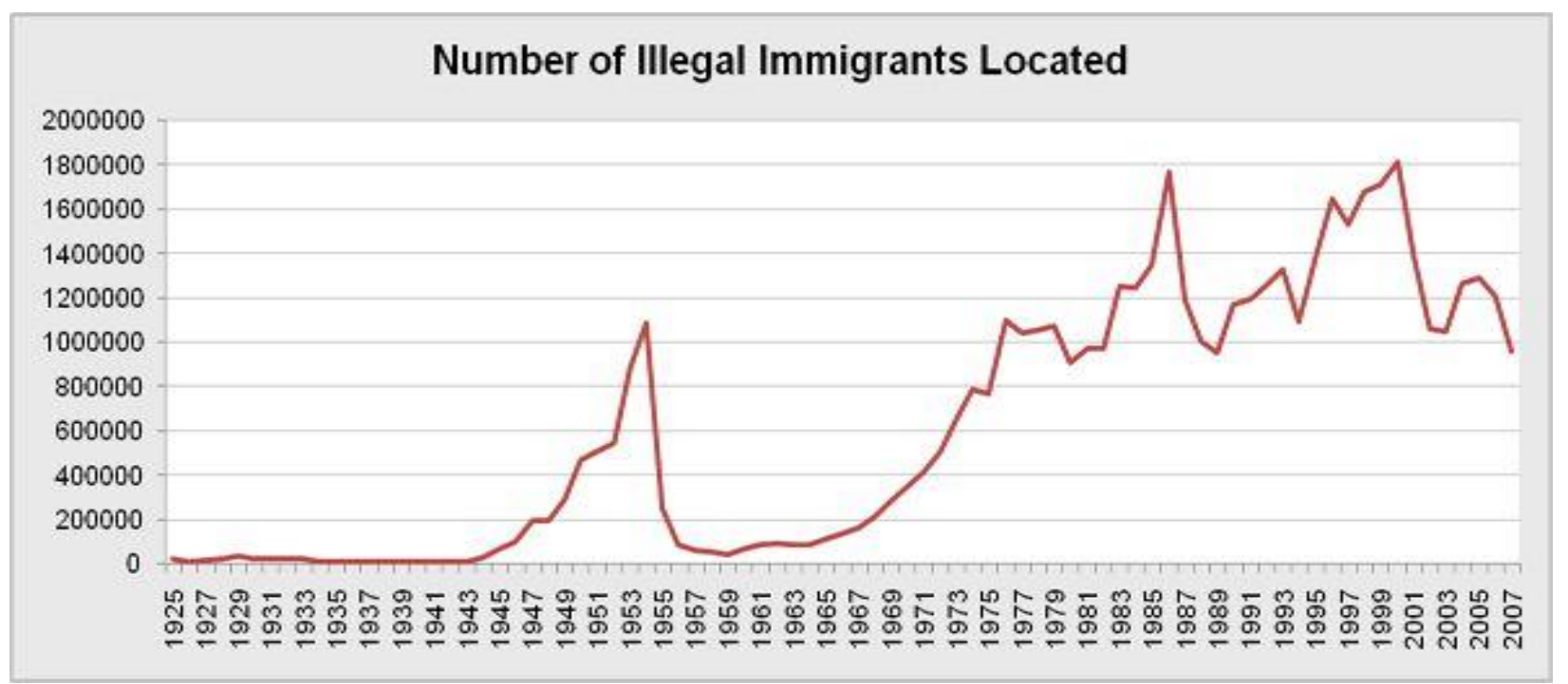

Figure 1. The number of illegal immigrants located.

Source: Department of Homeland Security. Retrieved from http://www.project.org/info.php?recordID=447

Table 1

Deported Aliens Report 1966-1975

\begin{tabular}{llcl}
\hline Year & Total number of deported aliens & Total number of deported Mexicans & The percentage of Mexicans \\
\hline 1966 & 138.520 & 89.751 & 65 \\
1967 & 161.608 & 108.327 & 67 \\
1968 & 212.057 & 151.705 & 72 \\
1969 & 283.557 & 201.636 & 71 \\
1970 & 345.353 & 277.377 & 80 \\
1971 & 420.126 & 348.178 & 83 \\
1972 & 505.949 & 430.213 & 85 \\
1973 & 655.968 & 576.823 & 88 \\
1974 & 788.145 & 709.959 & 90 \\
1975 & 766.600 & 680.392 & 89 \\
\hline
\end{tabular}

Resource: US Immigration and Naturalization Service, Annual Reports, fiscal years 1966-1975.

Illegal immigrants mainly lived in southwestern cities and border cities such as Los Angeles, El Paso, New York, New Jersey, Chicago, Miami, Denver, and Detroit. There are two kinds of illegal immigrants: one is illegal entrant from the southwestern border; the other has expiration visa. Many illegal immigrants with 
expired visa lived in New York and New Jersey.

Did illegal immigrants influence Americans' life? Yes, particularly American workers' salary. Most of illegal immigrants worked in labor-intensive field, such as agriculture and industry. According to North /Houston study in 1976, fewer than one-quarter were employed in skilled jobs, and the majority (16\%) were craft workers. Many illegal aliens worked longer hours and enjoyed lower salaries than American workers (Vialet, 1977, p. 17). According to north Houston research, the average hourly salary of illegal immigrant was 2.66 dollars, while American workers' salary was 4.47 dollars (Vialet, 1977, p. 14). To some degree, illegal immigrants reduced Americans' salary.

Table 2

INS Permanent Positions by Budget Activity, Fiscal Years 1976 and $1977^{1}$

\begin{tabular}{|c|c|c|c|}
\hline Budget activity & 1976 & 1977 & Percentage change $(\%)$ \\
\hline Border inspect & 1419 & 1591 & 7.0 \\
\hline Verification & 685 & 785 & 15.0 \\
\hline Deportation and arrest & 827 & 1031 & 25.0 \\
\hline Naturalization & 473 & 473 & 0.0 \\
\hline Border patrol & 2434 & 2439 & 0.2 \\
\hline Investigation of aliens & 1304 & 1504 & 15.0 \\
\hline The record of immigration and naturalization & 1057 & 1057 & 0.0 \\
\hline General administrative fee & 561 & 571 & 2.0 \\
\hline Total fee & 8670 & 9451 & 7.0 \\
\hline
\end{tabular}

Resource: Vialet, 1977; House Appropriations Committee hearing, 1976, pp. 4, 633.

Secondly, the anti-immigration social context, including interest groups and public opinion. Under the recession of economy, public opinion hoped that the government could take measures to control illegal immigrants. For example, according to NBC investigation and 1982 Roper, two thirds people called for the government to take serious measures to control illegal immigrants. They were afraid that illegal immigrants seized jobs and shared public benefits. In 1982, according to a public opinion investigation, the $84 \%$ public were concerned the number of illegal immigration, according to 1983 Gallup investigation, $79 \%$ people supported government to seriously control illegal immigrants (Espenshade, 1993, p. 189). In 1975, the New York Times called for employer sanction because illegal immigrants came to America in order to find good jobs and there were six to seven million illegal immigrants every year (Shannon, 1975, p. 32).

What's more, interest groups had different opinions about illegal immigrants. Minority groups and human rights groups persisted in liberal idea about immigration policy. Although they were against illegal immigration, they called for soft measures. They opposed a large-scale deportation policy. In 1970 and 1971, the National Defense Department attacked Chinese restaurants in New York, which intrigued Chinese Americans' opposition. In 1972, a Mexican Chicano leader declared that government's behavior was illegal. On the contrary, labor union and population and environment organizations called for serious measures about illegal immigrants, because illegal immigrants damaged the environment and leaded to the increase of population.

Thirdly, INS and government also took some measures to control illegal immigrants. INS should be responsible the increase of illegal immigrants, so INS paid more attention to border control. As the following

\footnotetext{
${ }^{1}$ INS budget office.
} 
table 1976-1977 shows, border control fee dominated in budget.

In addition, the government also took measures to limit illegal immigrants enjoying public benefits. From 1970 to 1980, the federal government enacted some legislation, which limited the rights of illegal immigrants, such as supplemental security insurance, assistance children program, children's loans, unemployment compensation, food aid programs. It means an illegal immigrant cannot enjoy public benefits, including insurance benefits, unemployment fee and medicinal insurance and training benefits. In 1974, American president Ford also met the Mexican president and discussed the illegal immigrants. The two countries agreed to take concerted action to control illegal immigration.

However, INS and government cannot resolve illegal immigration issue. In the 1970s, it was time to enact new immigration legislation. Actually, before Immigration Reform and Control Act of 1986, there was no special immigration legislation about illegal immigration.

\section{Compromising Legislation}

Since the 1970s, more and more Congressmen were concern illegal immigrants. However, till 1986, the IRCA was enacted. The biggest characteristic of the IRCA is combining employer sanction and amnesty policy. In other words, it was a compromising legislation and an attempt to balance the interests of different interest groups.

The IRCA mainly includes five parts: the first part was employer sanction. It was the first time to put employer sanction into legislation. In details, the employer will be fined if they employ illegal immigrants; the first time penalty was 250-2,000 dollars; the second time was 2,000-5,000 dollars; the third time was 3,000-10,000 dollars; the fourth time was six months' prison and 3,000 dollars fine. In order to enforce employer sanction, employers should check employees' following certifications: American passport, naturalization certification, social security card, green cards, birth certification or other cards such as driver license, which was supported by federal government or state government.

The second part of the IRCA was amnesty policy. In 1986, 2.7 million illegal immigrants were legalized. Amnesty policy included workers program and special workers program. The people, who came to America before January 1 of 1982, can apply for this project. They get temporary legalized certification after 18 months. They can get green card if they grasp English and American history. Special workers program means that illegal immigrants, who worked at least 90 days within three years, can get temporary citizens' certification. The people who apply for this program can get permanent citizenship. Finally, total 2.7 million people were amnestied and the 70\% came from Mexico (Orrenius, 2001).

The third part of the IRCA was border control. Congress appropriated INS 422 million dollars in 1987 and 419 million dollars in 1988 to control illegal immigration. At least 184 million dollars was used for border control.

The fourth part of the IRCA was anti-discrimination measures: it is illegal if employers discriminate employees because of national origins. Under Judiciary Department, there was a special committee, which dealt with unfair complaints related with immigration policy. Complaint must provide the discrimination proof within 180 days. If proof was enough, then employer should pay for 1000 dollars, the highest fine was 2,000 dollars, and Judiciary Department also asked employers to return two years' salary. In addition, IRCA asked General Accounting Office (GAO) to research discrimination issue every year. Congress would abolish it if 
GAO found that there was lots of discrimination phenomenon.

The fifth part of the IRCA was H2A program. It was the first time to build H2A program. Under this project, Labor Department must give assurance that employed workers will not damage and influence domestic workers' benefits. H2A was different from $\mathrm{H} 2$, as the employer need to turn in certification before they employ workers in six days and the Labor Department must verify certification in 20 days. During the period of waiting, the employers can employ native workers. Employers provide H2A accommodation and the cost of living and supplementary fee.

Actually, the IRCA included soft and hard measure. Amnesty policy, temporary workers and anti-discrimination measures belong to soft measures; while border control and employer sanctions belong to hard measures. Therefore, IRCA was a legislation of compromise. The reason of the compromise is that interest groups influence Congress; different interest groups had different ideas about immigration reform. Especially, employer sanction and amnesty policy were the most controversial problems.

\section{Employer Sanction Conflict}

In the 1970s, Congressmen began to think about making new immigration legislation. However, it was until 1986, the IRCA was enacted. The biggest reason was that there were great disputes about employer sanctions and amnesty policy.

Generally speaking, it is easy to make agreement to control illegal immigrants by border control and the aid to INS and help illegal immigrants sending countries in Congress. However, there was a great dispute about employer sanction. Some Congressmen thought the aim of illegal immigrants, who come to America, was looking for job. Employer sanction will resolve illegal immigration problem because it can diminish the chance of job. So employer sanction should be put in legislation. Actually, employer sanction was put up in 1952, but it did not pass because of western states "Congressmen and interest groups" opposition. Since 1970s, Congress often put up employer sanction; unfortunately, it failed. There was a long struggle between supporters and oppositions.

On the one hand, the supporters of employer sanction were as following: American Federal Labor and Congressional Industry Organization (AFL-CIO) strongly supported employer sanction; they agreed that illegal immigrants influence domestic salary and reduce the life native workers. Therefore, it was necessary to enforce employer sanction, because more illegal immigrants with expired visas are than illegal entrants (The knowing employment of illegal immigrants, 1982, p. 167). Zero Population Growth organization also supported employer sanction, which both reduced the opportunity of illegal immigration employment and Americans get benefits from employment market (S. 2252, Alien adjustment and employment act of 1977, 1978-1979, p. 124).

In addition, some Congressmen, including Senator Edward Kennedy and Wyoming senator Alan sided with employer sanction. American president and administrative organizations also supported employer sanction, such as INS, Labor Department and the State Department (The knowing employment of illegal immigrants, 1982, pp. 3-29).

On the other hand, the Opponents of employer sanction are as followings: Small business groups and agriculture groups were against employer sanction because they endure the burden of illegal immigrants (The 
knowing employment of illegal immigrants, 1982, p. 124). Growing groups were afraid of their harvest. ${ }^{2}$ Latino Unions and human rights unions were afraid that employer sanction would lead to discrimination (The knowing employment of illegal immigrants, 1982, p. 166). Besides, some Congressmen, who were from immigration districts strongly opposed employer sanction. They paid more attention to the need of agriculture labors. For example, senator Harrison Schmitt, who was from New Mexico thought employer sanction was controversial; most of the illegal immigrants were from Mexico; so it was worthwhile to strengthen border control, but employer sanction would not stop illegal immigration. What's more, employer sanction should lead to small business's chaos and discrimination towards the minority. He was afraid that employer sanction would lead to southwestern small businesses' bankrupt; he suggested that Congress could take measures to let Mexican to come to America seasonally (The knowing employment of illegal immigrants, 1982, pp. 45-48). In the 1970s, congressmen Hon Leo J Ryan, who was from California thought illegal immigrants deteriorate unemployment; about 2-3 million illegal immigrants seized jobs and reduced the agricultural salary; as a result, farmers only looked for the other channel to employ workers, so it was very important to resolve employment issue if Congress wanted to solve illegal immigration (Illegal aliens, 1975, pp. 181-186).

Thus, the process of legislation was very slowly because of the dispute of employer sanction policy, even if House passed the bill of employer sanction, bill failed in Senate. In March of 1972, Senator Peter W Rodino JR and Emanuel Celler put up HR1618, whose aim is to eliminate the chance of illegal immigrants employment. This bill was passed in September of 1972 (Illegal aliens, 1973, pp. 2-3). In 93rd Congress, House passed HR982, which made it illegal to employ illegal immigrants if employers knew they were illegal, while Senate did not take action.

On Sep 30th of 1981, the Senate Judiciary Department held a conference about employer sanction. In this conference, disparity still existed. Immigration and Refugees Policy Committee supported employer sanction, while AFL-CIO called for more fines. American Citizens' Rights Committee, American Latino Citizen Union and Mexican American Legal Defense and Education Committee opposed it (Summary of hearings held by the Senate Judiciary Subcommittee, 1983, p. 11).

The disparity between supporters and opponents were over how to verify the real certification of illegal immigrants and how to avoid discrimination. Supporter cared the steps of employer sanction, while opponents paid more attention to anti-discrimination measures and how to verify illegal immigrants, while Agriculture Department paid more attention to the supply of labor and enlarging H2 program (Immigration Reform and Control Act of 1983, 1983, p. 25).

Therefore, supporters of employer sanction hoped to reduce illegal immigration by employer sanction, while opponents were afraid that the burden of employer sanction and lack of labors, such as agricultural interest groups, commercial interest groups, the minority and human rights groups cared about discrimination. Finally, it was not passed until in 1985.

\section{Amnesty Policy Conflict}

Edward Kennedy was the first person to put up with Amnesty policy HR 8713. In 1977, the president organized people to research illegal immigration issue. Some people put up amnesty policy, under this project,

\footnotetext{
${ }^{2}$ Retrieved from http://andrsn.stanford.edu/Other/illegal.html
} 
the people, who came to America before Jan the first of 1970 can get permanent residence, while the people, who came to America after Jan the first of 1970 can get temporary residence and will not be deported in 5 years (Osuna, 1986). The 94th Congress began to take it seriously in October of 1977 (Osuna, 1986). ${ }^{3}$ In this session of Congress, conservative groups strongly opposed, while liberalists supported (Osuna, 1986). President Carter considered amnesty policy as useful measure to reduce exploration and domestic workers' benefits and avoiding deterrence working conditions. Latino Citizen Union, Textile Workers Organization, AFL-CIO and Judiciary Department also supported. Zero Population Organization opposed as they thought amnesty policy could increase domestic unemployment and encourage more illegal immigrants (Osuna, 1986).

In 1981, when Reagan put up amnesty policy, he suggested legalizing the people, who came before Jan 1 of 1980; illegal immigrants can get permanent citizenship if they live in America for 10 years; they can apply for citizenship if they satisfy some requirements; during the 10 years, illegal immigrants cannot bring their family members and cannot enjoy public benefits. This suggestion intrigued a great debate. For example, Latin citizen association welcomed it, but it also concerns the followings: 10 years were too long; it was unfair that illegal immigrants pay for taxes but not enjoy public benefits; illegal immigrants' direct relatives should apply for permanent citizenship; these aliens should enjoy educational, medicinal and social security benefits (Legalization of illegal immigrants, 1982, pp. 214-221).

Some administrative organization supported it, such as Agriculture Department, Judiciary Department and Immigration Policy and Committee also supported (Legalization of illegal immigrants, 1982, p. 3). AFL-CIO supported amnesty policy but thought that 10 years were too long, illegal aliens had to accept the low salary because they cannot enjoy public benefits (Legalization of illegal immigrants, 1982, pp. 206-208). Zero Population opposed and thought it encouraged exploitation because illegal alien cannot enjoy public benefits (Legalization of illegal immigrants, 1982, p. 130). State Department thought measure was controversial, amnesty policy and employer sanction should be combined (Legalization of illegal immigrants, 1982, p. 17). Finally, the bill did not pass.

Therefore, the minority and some administrative organizations supported amnesty policy, while conservative organizations, such as Labor Union and Zero Population organization opposed it. From 1977-1982, it was very difficult to get agreement in Congress. In 1982, when Simpson-Mode Li motion was presented, the opposition idea was that the time of amnesty and whether legalization immigrants enjoy public benefit. Finally, there was an agreement after 97th, 98th, and 99th Congress.

\section{Simpson-Mode Li Motion}

The bill about immigration reform was hard to pass because there was a great disparity about employer sanction and amnesty policy. It was interesting that while some interest groups supported amnesty policy but against employer sanction policy, such as citizen association and the minority organization, other interest groups opposed amnesty policy but supported employer sanction such as environment association. Under this context, Simpson-Mode Li motion appeared.

Actually, IRCA is also called Simpson-Mode Li motion. It combined employer sanction and amnesty policy.

\footnotetext{
3 S. 2252, 95th Cong., 2d Sess. 123 CONG. REC. 35, pp. 792-94 (1977); H. R. 9531, 95th Cong., 1st Sess., 123 CONG. REC. 33,493 (1977). The two bills, introduced by Sen. James Eastland and Rep. Peter Rodino, were identical. Bevilacqua, Legal Critique of President Carter's Proposals on Undocumented Aliens, 23 CATH. LAW. 286.
} 
There were following requirements about employer sanction: the first time was warning and fine 1,000 dollars; the second time was 2000 dollars fine, after the fine was 1,000 dollars or six months' presentment or both; the requirements of amnesty policy were as followings: the aliens who came to America since Jan of 1978 can get permanent residence; the people, who came to America since Jan 1 of 1980 can get temporary residence (Summary of HR 5837, 1982, pp. 537-541).

This legislation was relatively comprehensive; however, it was not specific because it did not satisfy opposition of employer sanction's requirements. For example: how to reduce the burden of employer and satisfy the need of labors. In amnesty policy field, the bill only referred to the range of amnesty policy and did not explain whether illegal aliens enjoy the public benefits. Finally, it failed. In 1982, Congress discussed it again. In House, it was HR5872 and it was S2222 in Senate.

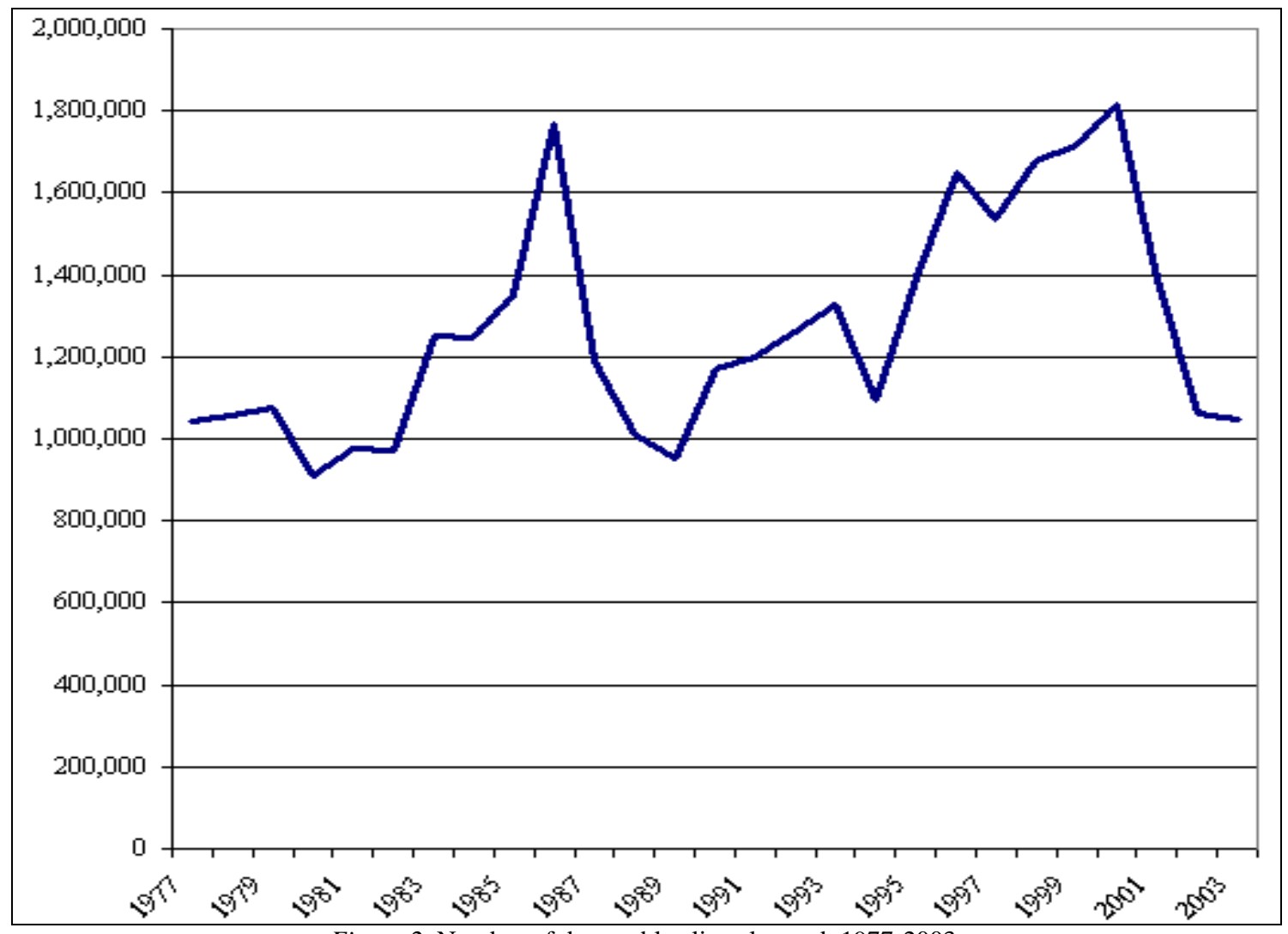

Figure 2. Number of deportable aliens located, 1977-2003.

Source: Department of homeland security yearbook of immigration statistics.

In this session of Congress, the minority groups still opposed employer sanction. Businessmen and agriculture groups also opposed; both of them did want to become the agent to check the aliens; finally, Republican also opposed. About amnesty policy, minority interest groups hoped that policy was open while others wanted to limit to the range of amnesty policy. In the house, there was an agreement about amnesty policy, and the disparity was how to enforce. In the senate, the debate about amnesty policy was the time of amnesty and the cost of amnesty (Summary of HR 5837, 1982, p. 137). Finally, it failed again. In 1983, the 98th session of Congress, Simpson added a provision - the people cannot enjoy public benefits in three years, 
in House, it passed. But in Senate, disparity still existed and it did not pass. In addition, when Congress election came, election was primary and immigration was set aside. In 1985, Senate passed bill, House also followed. Finally, in 1986, IRCA was passed on October of 17th of 1986. In Senate, the result of vote was 63:24 while in House, it was 238:173.

So, IRCA was a result of compromise legislation, from the both content and decision-making perspective. Because there was debate among interest groups about employer sanction and amnesty policy, Congress tried to seek balance between them. Finally, Congress enacted legislation as a result of requirements of supporters and opponents.

\section{Evaluation of IRCA}

IRCA combined soft and hard measures. After its enforcement, did it work? Actually, in the short term, it worked; in the long run, it failed. In detail, as followings:

Firstly, generally speaking, in the short term, it reduced the number of illegal immigration. Then the number of illegal immigrants increased again. According to GAO report, from 1987-1988, the number of illegal immigrants was on the decline because of employer sanction.

From this table, we can see that from1987-1989, the number of deportable illegal immigrants were on the decline. However, according to GAO report, within three years of legislation enforcement, the number of border patrol arrests was reduced by 50\%, then it restored to 1985's level (Immigration reform, 1987, p. 5).

Actually, the decline of illegal immigration was not completely attributed to employer sanction. Because of amnesty policy, about 2.7 million illegal immigrants became legal. For example, in 1986 INS arrested 1.7 million illegal immigrants; in 1989, it decreased to 900,000. Population specialists analyzed that half of the reason for the decline of illegal immigrants was amnesty policy. In 1993, the number of arrested illegal immigrants increased to 1.3 million, which was similar to 1985's level (Baker, 1997).

Secondly, employer sanction did not finally resolve illegal immigration issue. Several reasons can account for it. One reason was that there was lack of strict enforcement. Actually, employer sanction was not serious, which paid attention to education not sanction (Fix \& Hill, 1990). In other words, it did not work as deterrence effect.

The other reason why employer sanction failed is that there were no valid measures to verify the real certification of illegal aliens. There were several steps to enforce employer sanction: workers should turn in two documents: citizenship certification or employment authorization. Employment appliers must fill in I-9 forum, which was supervised by INS and Labor Department, employment apply can work only if these documents pass. At the beginning of legislation enforcement, the number of illegal immigrants was on the decline because employer did want to recruit South American workers. Following, the number of illegal immigrants increased because of fraud document.

Another reason was that the US needs cheap illegal labors. In some places, employers still employed illegal immigrants even if they knew they were illegal. For example, in Illinois, according to the 1984 survey, the $70 \%$ bosses still employed the illegal immigrants even if they knew the employees were illegal. Actually, there was employer sanction in California, Florid and Las Vegas before IRCA. But none of the people enforced it, which means employer sanction was not welcomed. After IRCA, employer sanction was not seriously enforced, because of fraudulent documents. Scholar Chiswick regarded employer sanction as a tiger without 
teeth, non-serious supervising system and fraudulent document cannot reduce the number of illegal immigrants (Fix \& Hill, 1990, p. 95). Urban Institute evaluated that there were three to five million illegal immigrants from 1980-1986 and the annual increase of illegal immigrant was 200,000 (Laham, 2000, p. 126; Summary of S. 1200-The Immigration Reform and Control Act of 1986, 1986). In 1997, INS evaluated that there were five million illegal immigrants; the annual increase of illegal immigrant was 275,000 (Congressional Quarterly Almanac, 99th Congress, 1986, p. 118). So, employer sanction did not work finally.

Thirdly, amnesty policy satisfied the need of labors but did not resolve illegal immigration issue. In amnesty program, $71 \%$ people were from Mexico, in special agriculture workers program, $81 \%$ appliers were from Mexico. In the first program, 93\% people, who applied for the project passed, in special workers project, $87 \%$ appliers passed. Most of the legalized people lived in immigration districts, such as the $54 \%$ legalized people in California, 19\% legalized people in Texas, seven percent legalized people in Illinois, the six percent in New York (Orrenius \& Zavodny, 2001). So, we can see that illegal immigrants in agriculture were main resource of amnesty objective. It was useful for the development of agriculture; however, it also potential encouraged the future illegal aliens. According to Federal Reserve Bank of Dallas report, amnesty policy did not encourage illegal immigrants and control illegal immigrants (Orrenius \& Zavodny, 2001).

\section{Conclusion}

In conclusion, IRCA is a result of compromise, including soft and hard measures. IRCA mainly contains two methods to control illegal immigrants, including employer sanction and amnesty policy. In other words, IRCA is the result of a balance of benefits of different groups and the role of Congress is weak. IRCA was not been enacted until 1986. Two reasons can account for it. On one hand, interest group was powerful. On the other hand, illegal immigration was a controversial issue, someone enjoy benefits, while others pay for the cost. The lessons from IRCA are as followings: congress should be more powerful and comprehensively consider illegal immigration policy.

Current comprehensive immigration reform has learned some lessons from IRCA, which combines legal immigration and illegal immigration reform. However, under the influence partisanship and interest groups, comprehensive immigration reform, which started in 2006, has not made some process by now. Therefore, Congress should learn all the lessons from IRCA, including coordination the internal contradiction and reducing the influence of interest groups.

\section{References}

Baker, S. G. (1997). The "amnesty" aftermath: Current policy issues stemming from the legalization programs of the 1986 Immigration Reform and Control Act, bean edmonston and passel, 1990 INS 1994. International Migration Review, 31(1), $5-27$.

Congressional Quarterly Almanac, 99th Congress. (1986). 1st Session. Congressional Quarterly. Washington, DC.

Espenshade, T. J. (1993). An analysis of public opinion toward undocumented immigration. Population Research and Policy Review, 12(3), 189-224.

Fix, M., \& Hill, P. 1 T. (1990). Enforcing employer sanctions: Challenges and strategies. Washington, D.C.: Urban Institute; Lanham, MD: Distributed by University Press of America.

House Appropriations Committee hearing, Department of State, Justice, and Commerce, the Judiciary, and Related Agencies. (1976). Part 4 (pp. 4, 633). Appropriations for 1977, 94th Cong, 2d session.

Illegal aliens: A review of hearings conducted during the 92d Congress (serial no. 13, pp. 1-5), Ninety-third Congress, first session. (1973). United States. Congress. House. Committee on the Judiciary. Subcommittee No. 1.Washington, US Govt. 
Print. Off.S. 2252, Alien adjustment and employment act of 1977: hearings before the Committee on the Judiciary, United States Senate, Ninety-fifth Congress, second session, on S. 2252. (1978-1979). PART 1. United States. Congress. Senate. Washington: US Govt. Print. Off.

Illegal aliens: hearings before the Subcommittee on Immigration, Citizenship, and International Law of the Committee on the Judiciary, House of Representatives, Ninety-fourth Congress, first session, on H. R. 982 and related bills. (1975). United States. Congress. House. Committee on the Judiciary. Subcommittee on Immigration, Citizenship, and International Law. Washington: US Govt. Print. Off.

Immigration reform: Status of implementing employer sanctions after one year: Report to Congress. (1987). United States General Accounting Office, Washington, DC: GAO.

Immigration Reform and Control Act of 1983: hearing before the Committee on Agriculture, House of Representatives, Ninety-eighth Congress, first session, on H.R. 1510. (1983). United States. Congress. House. Committee on Agriculture. Washington: US G.P.O.

Laham, N. (2000). Ronald Reagan and the politics of immigration reform. New York: Praeger.

Legalization of illegal immigrants: hearing before the Subcommittee on Immigration and Refugee Policy of the Committee on the Judiciary, United States Senate, 97th Congress, second session, on legalization of illegal immigrants, October 29, 1981, United States. (1982). Congress. Senate. Committee on the Judiciary. Subcommittee on Immigration and Refugee Policy. Washington: US, G.P.O.

Orrenius, P. M. (2001). Do amnesty programs encourage illegal immigration? Evidence from IRCA, Research Department, Federal Reserve Bank of Dallas. Retrieved from http://www.dallasfed.org/research/papers/2001/wp0103.pdf

Orrenius, P. M., \& Zavodny, M. (2001). Do amnesty programs encourage illegal immigration? Evidence from IRCA. Retrieved from http://www.dallasfed.org/research/papers/2001/wp0103.pdf

Osuna, J. P. (1986). Amnesty in the IMMIGRATION Reform and Control Act of 1986: Policy Rationale and Lessons from Canada. Retrieved from http://www.auilr.org/pdf/3/3-1-4.pdf

Shannon, W. V. (197, January 14). The illegal immigrants. New York Times (1923-Current file), p. 32.

Summary of hearings held by the Senate Judiciary Subcommittee on Immigration and Refugee Policy, July 1981-April 1982, prepared for the Subcommittee on Immigration and Refugee Policy of the Committee on the Judiciary. (1983). United States Senate by the Congressional Research Service, Library of Congress. Washington: US G.P.O.

Summary of HR 5837 "immigration reform and control act of 1982" Immigration Reform and Control Act of 1982: joint hearings before the Subcommittee on Immigration, Refugees, and International Law of the Committee on the Judiciary, House of Representatives and Subcommittee on Immigration and Refugee Policy of the Committee on the Judiciary, United States Senate, 97 Congress, second session, on H.R. 5872, S. 2222 ... April 1 and 20, 1982. (1982). United States. Congress. House. Committee on the Judiciary. Subcommittee on Immigration, Refugees, and International Law. Washington: US G.P.O.

Summary of S. 1200-The Immigration Reform and Control Act of 1986. (1986). IM whorm: Subject File. Ronald Reagan Library.

The knowing employment of illegal immigrants: hearing before the Subcommittee on Immigration and Refugee Policy of the Committee on the Judiciary, United States Senate, Ninety-seventh Congress, first session, on employer sanctions, September 30, 1981. (1982). United States. Congress, Senate. Committee on the Judiciary: Subcommittee on Immigration and Refugee Policy. Washington : US G. P.O.

Vialet, J. C. (1977). Illegal aliens: Analysis and background prepared for the use of the Committee on the Judiciary, US House of Representatives. The Education and Public Welfare Division, Congressional Research Service, Library of Congress, Ninety-fifth Congress, first session. Washington: US Govt. Print. 